\title{
Audience constructions of fake news in Australian media representations of asylum seekers
}

\section{A critical discourse perspective}

\author{
Ashleigh L. Haw \\ The University of Melbourne
}

In recent years, the term 'fake news' has gained considerable traction in scholarly and public discourse. While fake news is increasingly attributed to declining audience trust, we know little about how publics are making sense of the concept. To address this, I discuss findings arising from interviews with 24 Western Australian media consumers who offered their perspectives on Australian news coverage of asylum seekers. Combining Critical Discourse methods with Rhetorical Analysis, findings highlight how participants evaluated misinformation and disinformation about asylum seekers and in particular, how some adopted a discourse of 'fake news' to delegitimise perspectives that oppose their own stance. Discussed alongside Egelhofer and Lecheler's (2019) theoretical framework of the fake news 'label', I argue that by understanding how audiences discussed fake news before the concept rose to prominence in 2016, scholars can meaningfully examine discursive patterns within social constructions of fake news across numerous contemporary and historical contexts.

Keywords: fake news, media, audiences, critical discourse analysis, Australia, asylum seekers

\section{Introduction}

The digital revolution has brought about fundamental shifts in how societies are informed about world events. With an abundance of information easily accessible through a variety of mediums, it can be challenging for citizens to discern credible from unreliable information, which ultimately impacts how we make sense of news media messages (Tsfati 2003). Factual inaccuracies, hoaxes, sensationalism, and distortion have all led citizens to question the credibility of journalism (Tsfati 
and Cappella 2003), leading to calls for greater accountability and transparency in the reporting of political news (McBride and Rosenstiel 2013). An issue that has recently risen to prominence during these discussions is fake news.

From the controversially close Brexit referendum in the United Kingdom to Donald Trump's narrow victory in the 2016 United States presidential election, we have witnessed a surge of interest in fake news as a socio-political phenomenon. In fact, the Collins Dictionary declared 'fake news' as 2017's word of the year (Flood 2017). Fake news, however, is not a new phenomenon. Prior to Trump's election, it was understood as political satires, parodies, and news propaganda (Baym 2005). In recent years, however, the term has become a staple in both scholarly and everyday discourse - both in the context of pointing out false information and for discrediting the work of traditional news organisations.

Several scholars argue that fake news distorts public debate and stifles democratic decision-making (Allcott and Gentzkow 2017; Brummette, DiStaso, Vafeiadis and Messner 2018). As Van Duyn and Collier explain:

Talking about fake news may have wide-ranging consequences for whether individuals trust news media and the standards with which they evaluate it and by extension, democratic outcomes $(2019,31)$.

It is therefore timely to investigate how audiences make sense of fake news in political communication.

In this paper, I present the findings from research combining Critical Discourse Analysis (Fairclough 1992) with Rhetorical Analysis (Billig 1991) to examine how 24 Western Australians framed their perceptions of Australian news depictions of people seeking asylum. Asylum seekers were chosen as a case study due to Australia's highly polarised stance on the issue (Higgins 2017). Furthermore, as most of the general public lacks direct contact with people from asylum seeking backgrounds, they are exposed to the topic primarily through news discourse (Muller 2016). Australian coverage of the issue, however, has been routinely found to portray asylum seekers in a negative light (e.g. Clyne 2005; Ellis, Fulton and Scott 2016; Lueck, Due and Augoustinos 2015; Pickering 2001). Additionally, fake news has been found to feature heavily in depictions of migrants and asylum seekers (Juhász and Szicherle 2017; Sutherland and Dykstra-DeVette 2018), yet audience responses remain under-investigated.

I situate my findings within the theoretical framework proposed by Egelhofer and Lecheler (2019) who proposed two important dimensions to investigating audiences' conceptions of fake news: fake news as a genre and fake news as a label. As my findings will demonstrate, even before 'fake news' became a popular facet of our media vocabulary, Australian political news audiences drew on several of the same discursive elements observed in discussions of fake news, demonstrating 
conceptions of fake news as both a label and a genre, in line with Egelhofer and Lecheler's framework. This paper unpacks some interesting discursive features of these constructions, situating them within the emerging literature surrounding conceptions of fake news, while highlighting the implications for our understanding of how audiences appraise the increasingly polarising nature of political news discourse in the digital era.

\section{Trust and mistrust in the era of 'fake news'}

News audiences tend to favour media content they trust (Johnson and Kaye 2000; Tsfati and Cappella 2003), however in recent years, dwindling resources for fact checking - coupled with declines in editorial independence and investigative journalism - have led to a continual decline in publics' trust in news (Fisher, Park, Lee, et al. 2019). The literature suggests two leading factors for this: the perceived accuracy of the information presented (Alcorn and Buchanan 2017; Fisher, et al. 2019; Park, Fisher, Lee, et al. 2020); and powerful elites using media messages for agenda setting rather than information sharing purposes (McCollough, Crowell and Napoli 2017; Newman and Fletcher 2017). At the centre of these discussions are rising concerns about fake news. For instance, the 2020 Digital Media Report indicated that Australians are increasingly voicing concerns about fake news when discussing their degree of trust in the media (Park, et al. 2020). To fully understand this, however, further exploration of audience perspectives is warranted.

\section{Conceptualising 'fake news'}

Historically, 'fake news' has been applied to a wide range of media texts, such as political satires, news parodies, false advertising, and propaganda (Tandoc, Lim and Ling 2018). For instance, it was initially understood as political satire such as The Onion or The Daily Show, both of which are intended as entertainment (Baym 2005). In the lead up to the 2016 US Presidential election, however, a spike in news texts containing false information started to gain traction, especially on social media (Cooke 2017). This led to concerns about how this phenomenon might impact the outcome of the election, as well as democracy more generally (Allcott and Gentzkow 2017).

Some scholars define fake news as intentionally fabricated content masquerading as factual information (Alcott and Gentzkow 2017; Bakir and McStay 2017). By this definition, fake news encompasses content that is both verifiably false and deliberately produced for monetary and/or ideological gain. A broader 
definition would, however, situate fake news within the larger context of misinformation (i.e. the inadvertent sharing of false information), and disinformation (the deliberate distortion of facts and/or presentation of fabricated stories) (Wardle 2017; Wardle and Derakshan 2017). Others, however, have cautioned against such a broad conceptualisation, noting that well-intentioned news sources can (and do) present factual inaccuracies that are not comparable to deliberate disinformation (Gelfert 2018).

The term 'fake news' is also commonly employed as a mechanism for voicing opposition to dissenting ideas. Here, the concept is co-opted by those in power, who use the term as an epithet to describe legitimate news material that counters their preferred ideological narrative (Dentith 2017; Farhall, Carson, Wright, et al. 2019; McNair 2018; Wardle and Derakhshan 2017). We saw this in action both during and following the election of former US president Donald Trump, who weaponised the term 'fake news' to delegitimise ideas presented by political opponents and undermine concerns about actual instances of misinformation and disinformation deployed during his campaign (McNair 2018).

Similar weaponisation has been observed in Australia. For instance, in their analysis of Australian political statements following the 2016 US Election, Farhall, et al (2019) found that conservatives routinely decried 'fake news' to discredit political rivals. Farhall, et al. (2019) contend that this can negatively impact citizens' trust in media and political institutions, undermining public understanding concerning important social issues. Similarly, Gelfert (2018) argues that the weaponisation of fake news in this way can stifle legitimate concerns about dubious content. Egelhofer and Lecheler (2019) closely examined this kind of weaponisation and in turn, proposed that fake news - in addition to being understood as a genre of media discourse encompassing the sharing of disinformation in the public sphere - can also be conceptualised as a label that is strategically deployed in order to delegitimise factual media content.

An issue that is no stranger to fake news, propaganda, and hyperbole is people seeking asylum. Research findings indicate that such coverage can drastically affect public perception, contributing to a crisis of confidence in migration and humanitarian policy directions (Philo, Briant and Donald 2013; Wodak and Krzyżanowski 2017). For instance, Zaryan's (2017) investigation into audiences perceptions of fake news revealed migration and humanitarian issues as popular topics of discussion, with many participants recounting instances of fake news surrounding asylum seekers.

Many argue that this kind of coverage contributes to the 'othering' and exclusion of people from migrant and asylum seeking backgrounds (Slavíčková and Zvagulis 2014). For instance, in their rhetorical analysis of fake news texts containing the tag 'refugees', Sutherland and Dykstra-DeVette (2018) found an abun- 
dance of stories depicting refugees as dangerous and taking away resources and opportunities from the wider society. Additionally, in her book How Australia Decides: Election Reporting and the Media, Sally Young (2011) documents multiple instances of misleading claims about asylum seekers within Australian election coverage between 2001 and 2008 , pointing out how the asylum issue became a central component of election campaigning during this period. Although it predates the widespread adoption of the fake news label, Young's work highlights the democratic implications of dubious claims about vulnerable groups, especially in terms of how these shape and reinforce public support for punitive policy directions that carry serious human rights implications. It is therefore critically important to understand how audiences make sense of fake news surrounding asylum seekers.

\section{The 'fake news' audience}

With internet users spending more time on social media, the power of fake news lies in its capacity to penetrate social spheres (Tandoc, et al. 2018). The endless quest for popularity on social media platforms means they lend themselves well to the propagation of unverified information, where an abundance of 'likes' and 'shares' can lend legitimacy to dubious claims (Lokot and Diakopoulos 2016). Critical media and socio-political scholars therefore face the urgent task of understanding the impact of fake news because of how readily audiences are duped by it and, in some cases, use it to influence the beliefs of others (Gil de Zúñiga and Diehl 2018). Fake news is, in turn, co-constructed by audiences (Tandoc, et al. 2018), yet we still know little about how audiences are evaluating and conceptualising fake news. The few empirical investigations into audience responses have tended to focus on the size of the fake news audience (relative to the broader news audience), largely to assess the reach of fake news (Allcott and Gentzkow 2017; Nelson and Taneja 2018). One study by Zaryan (2017), however, examined audience perspectives on fake news, finding that some saw the term as a strategy used by political elites to undermine counter ideas, while others felt that fake news encompasses any content that presents claims that can be disproven. Zaryan $(2017,67)$ concludes that deeper inquiries into what news consumers consider real and fake can pave the way for better understanding "the current pitfalls of our information economy".

A notable area of scholarly inquiry that warrants more attention relates to how audiences articulate discourses of 'fake news' and the potential implications for public deliberation. This paper therefore addresses the following research questions: 
1. What prominent discourses emerge when audiences discuss their trust in news coverage concerning a polarising topic in Australian politics (i.e. asylum seekers)?

2. How do these conceptualisations compare with discourses of 'fake news' observed in the literature?

\section{Research design}

\subsection{Participants, sampling and data collection}

The findings presented in this article derive from a larger study exploring audience perceptions of Australian news representations of asylum seekers (see Haw 2018). The aim was to shed light on how a sample of Australian media consumers reflect on news discourses about people seeking asylum, focusing on how they both reproduce and resist dominant discourses observed in the existing literature. To achieve this, I conducted semi-structured interviews with 24 Western Australians between May 2015 and April 2016. This time period is important as it pre-dates the 2016 US Presidential Election and thus, before 'fake news' became a popular term in discussions of political news.

To recruit my sample, I employed a combination of snowballing and purposive methods. Snowballing occurs when participants refer others to the study after taking part themselves (Noy 2008), and purposive sampling involves selecting participants because they meet a certain criteria (Willig 2008). Snowballing made it easier to identify and approach such participants, whereas purposive methods were necessary to ensure my sample encapsulated a diverse range of backgrounds and perspectives on asylum seekers.

Prior to their interviews, participants completed a brief, optional demographic questionnaire, capturing information on gender, age, religion, nationality, education, political stance, and asylum views (see Table 1). To ascertain participants' asylum stance, I asked them to discuss whether they believe Australia should assess asylum claims and provide protection to those determined as refugees. Interviewees who stated that Australia should resettle refugees $(n=11)$ were classified as having 'accepting' views, whereas those who objected were placed in the 'non-accepting' category $(n=5)$. Some participants $(n=8)$ stated that they consider themselves 'on the fence' about the issue, offering a combination of 'accepting' and 'non-accepting' perspectives. These interviewees were considered to hold 'ambivalent' views. 
Table 1. Participants' demographic details and stance on asylum seekers

\begin{tabular}{|c|c|c|c|c|c|c|c|}
\hline Pseudonym & Age & Gender & $\begin{array}{l}\text { Education } \\
\text { level }\end{array}$ & Nationality & Religion & $\begin{array}{l}\text { Political } \\
\text { preference }\end{array}$ & $\begin{array}{l}\text { Asylum } \\
\text { stance }\end{array}$ \\
\hline Beth & 36 & Female & $\begin{array}{l}\text { High School - } \\
\text { Year } 10\end{array}$ & $\begin{array}{l}\text { Australian- } \\
\text { Indigenous }\end{array}$ & Christian & $\begin{array}{l}\text { Australian } \\
\text { Labor Party }^{\star}\end{array}$ & $\begin{array}{l}\text { Non- } \\
\text { accepting }\end{array}$ \\
\hline Brooke & 29 & Female & TAFE $^{\star *}$ & Australian & Christian & $\begin{array}{l}\text { Australian } \\
\text { Labor Party }\end{array}$ & Ambivalent \\
\hline Gillian & 41 & Female & $\begin{array}{l}\text { High School - } \\
\text { Year } 12\end{array}$ & Australian & $\begin{array}{l}\text { Uniting } \\
\text { Church }\end{array}$ & $\begin{array}{l}\text { Australian } \\
\text { Greens }\end{array}$ & Accepting \\
\hline Ingrid & 73 & Female & $\begin{array}{l}\text { University - } \\
\text { Postgraduate }\end{array}$ & Australian & $\begin{array}{l}\text { Not } \\
\text { disclosed }\end{array}$ & $\begin{array}{l}\text { Not } \\
\text { disclosed }\end{array}$ & Accepting \\
\hline Jane & 57 & Female & $\begin{array}{l}\text { University - } \\
\text { Bachelor's } \\
\text { Degree }\end{array}$ & Australian & Atheist & $\begin{array}{l}\text { Labor- } \\
\text { Greens } \\
\text { (swing voter) }\end{array}$ & Accepting \\
\hline Jessica & 22 & Female & $\begin{array}{l}\text { University - } \\
\text { Bachelor's } \\
\text { Degree }\end{array}$ & Australian & Agnostic & $\begin{array}{l}\text { Australian } \\
\text { Greens }\end{array}$ & Accepting \\
\hline Jodie & 41 & Female & $\begin{array}{l}\text { University - } \\
\text { Postgraduate }\end{array}$ & Australian & Atheist & $\begin{array}{l}\text { Australian } \\
\text { Greens }\end{array}$ & Accepting \\
\hline Patsy & 68 & Female & TAFE & Australian & $\begin{array}{l}\text { Church } \\
\text { of } \\
\text { England }\end{array}$ & $\begin{array}{l}\text { Liberal Party } \\
\text { of } \\
\text { Australia }^{* * * *}\end{array}$ & Ambivalent \\
\hline Renee & 57 & Female & $\begin{array}{l}\text { University - } \\
\text { Postgraduate }\end{array}$ & Australian & $\begin{array}{l}\text { Roman } \\
\text { Catholic }\end{array}$ & $\begin{array}{l}\text { Labor- } \\
\text { Greens } \\
\text { (swing voter) }\end{array}$ & Accepting \\
\hline Susan & 59 & Female & $\begin{array}{l}\text { University - } \\
\text { Postgraduate }\end{array}$ & Australian & Atheist & $\begin{array}{l}\text { Australian } \\
\text { Greens }\end{array}$ & Accepting \\
\hline Zara & 25 & Female & $\begin{array}{l}\text { University - } \\
\text { Bachelor's } \\
\text { Degree }\end{array}$ & $\begin{array}{l}\text { Australian- } \\
\text { Pakistani }\end{array}$ & Islamic & $\begin{array}{l}\text { Australian } \\
\text { Labor Party }\end{array}$ & Ambivalent \\
\hline Katie & 28 & Female & $\begin{array}{l}\text { University - } \\
\text { Bachelor's } \\
\text { Degree }\end{array}$ & Australian & $\begin{array}{l}\text { Roman } \\
\text { Catholic }\end{array}$ & $\begin{array}{l}\text { Australian } \\
\text { Labor Party }\end{array}$ & $\begin{array}{l}\text { Non- } \\
\text { accepting }\end{array}$ \\
\hline $\mathrm{Al}$ & 19 & $\begin{array}{l}\text { Non- } \\
\text { binary }\end{array}$ & $\begin{array}{l}\text { High School - } \\
\text { Year } 12\end{array}$ & Australian & Atheist & $\begin{array}{l}\text { Australian } \\
\text { Greens }\end{array}$ & Accepting \\
\hline Adam & 29 & Male & TAFE & Australian & Agnostic & $\begin{array}{l}\text { Australian } \\
\text { Greens }\end{array}$ & Accepting \\
\hline Andrew & 30 & Male & $\begin{array}{l}\text { High School - } \\
\text { Year } 12\end{array}$ & Australian & $\begin{array}{l}\text { Not } \\
\text { disclosed }\end{array}$ & $\begin{array}{l}\text { Australian } \\
\text { Labor Party }\end{array}$ & Ambivalent \\
\hline
\end{tabular}


Table 1. (continued)

\begin{tabular}{|c|c|c|c|c|c|c|c|}
\hline Pseudonym & Age & Gender & $\begin{array}{l}\text { Education } \\
\text { level }\end{array}$ & Nationality & Religion & $\begin{array}{l}\text { Political } \\
\text { preference }\end{array}$ & $\begin{array}{l}\text { Asylum } \\
\text { stance }\end{array}$ \\
\hline Bryan & 45 & Male & $\begin{array}{l}\text { University - } \\
\text { Bachelor's } \\
\text { Degree }\end{array}$ & $\begin{array}{l}\text { Australian- } \\
\text { British }\end{array}$ & $\begin{array}{l}\text { Church } \\
\text { of } \\
\text { England }\end{array}$ & $\begin{array}{l}\text { Liberal Party } \\
\text { of Australia }\end{array}$ & $\begin{array}{l}\text { Non- } \\
\text { accepting }\end{array}$ \\
\hline David & 33 & Male & $\begin{array}{l}\text { University - } \\
\text { Postgraduate }\end{array}$ & $\begin{array}{l}\text { Australian- } \\
\text { Venezuelan }\end{array}$ & Catholic & $\begin{array}{l}\text { Australian } \\
\text { Greens }\end{array}$ & Accepting \\
\hline Don & 66 & Male & $\begin{array}{l}\text { High School - } \\
\text { Year } 10\end{array}$ & Australian & $\begin{array}{l}\text { Church } \\
\text { of } \\
\text { England }\end{array}$ & $\begin{array}{l}\text { Liberal Party } \\
\text { of Australia }\end{array}$ & $\begin{array}{l}\text { Non- } \\
\text { accepting }\end{array}$ \\
\hline Gary & 71 & Male & TAFE & Australian & $\begin{array}{l}\text { Church } \\
\text { of } \\
\text { England }\end{array}$ & $\begin{array}{l}\text { Liberal Party } \\
\text { of Australia }\end{array}$ & Ambivalent \\
\hline Luke & 34 & Male & $\begin{array}{l}\text { High School - } \\
\text { Year } 12\end{array}$ & Australian & $\begin{array}{l}\text { Not } \\
\text { disclosed }\end{array}$ & $\begin{array}{l}\text { Australian } \\
\text { Greens }\end{array}$ & Accepting \\
\hline Mark & 24 & M & $\begin{array}{l}\text { University - } \\
\text { Bachelor's } \\
\text { Degree }\end{array}$ & Australian & Catholic & $\begin{array}{l}\text { Liberal Party } \\
\text { of Australia }\end{array}$ & Ambivalent \\
\hline Reece & 24 & M & TAFE & Australian & $\begin{array}{l}\text { Not } \\
\text { disclosed }\end{array}$ & $\begin{array}{l}\text { Labor- } \\
\text { Liberal } \\
\text { (swing voter) }\end{array}$ & $\begin{array}{l}\text { Non- } \\
\text { accepting }\end{array}$ \\
\hline Sam & 28 & Male & $\begin{array}{l}\text { High School - } \\
\text { Year } 10\end{array}$ & Australian & Spiritual & $\begin{array}{l}\text { Not } \\
\text { disclosed }\end{array}$ & Ambivalent \\
\hline Tom & 66 & Male & $\begin{array}{l}\text { University - } \\
\text { Bachelor's } \\
\text { Degree }\end{array}$ & Australian & $\begin{array}{l}\text { Not } \\
\text { disclosed }\end{array}$ & $\begin{array}{l}\text { Not } \\
\text { disclosed }\end{array}$ & Ambivalent \\
\hline
\end{tabular}

* TAFE (Technical and Further Education) refers to vocational-focused institutions that provide qualifying courses under the Australian Quality Training Framework.

** The Australian Labor Party is a major centre-left political party, one of the two major parties in Australia.

*** The Australian Greens is a political party known for its core values of ecological sustainability, environmentalism, social justice, grassroots democracy, and peace/non-violence.

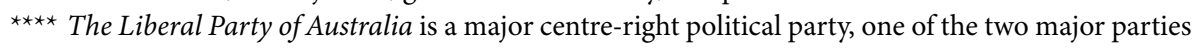
in Australia. It is currently in power, under the leadership of Prime Minister Scott Morrison.

During their interviews, participants were asked open-ended questions about: (1) their general stance on people seeking asylum, including Australia's policy responses; (2) their media engagement habits and preferences; and (3) their views concerning how the Australian media represents people seeking asylum. These questions included: 'what comes to mind for you when you hear the term asylum seeker?'; 'how do you feel about the Australian government's policies for 
people seeking asylum?'; 'how do you typically come across information about people seeking asylum?'; 'what kinds of media sources do you prefer to engage with and why?'; and 'what do you think about portrayals of asylum seekers in the Australian news media?' Interviews were audio recorded and transcribed verbatim, enabling in-depth analysis. To maintain confidentiality, participants' real names have been replaced with pseudonyms and any identifying details are omitted from all publications arising from this study.

\subsection{Analysis}

This research sought to go beyond merely ascertaining participants' responses to media representations and rather, examine how these ideas were articulated with consideration of interviewees' self-reported perspectives on the topic. I was therefore primarily interested in examining the language participants used to construct their perspectives on news coverage, including how these discussions relate to broader power structures that contribute to the marginalisation of people seeking asylum. To achieve this, I examined my interview data using Critical Discourse Analysis (Fairclough 1992). CDA is concerned with exploring how people draw upon collective values and norms to construct our ideas about the world (Titscher, Meyer, Wodak and Vetter 2000). Through its recognition of the various ideological functions language can serve, CDA allows scholars to identify how unequal power relations are reproduced and transformed through talk (van Dijk 2000). For this reason, CDA is useful in explorations of how publics evaluate mediated constructions of disenfranchised groups, such as asylum seekers.

I also employed Rhetorical Analysis (RA), which focuses on the argumentative and dialogical nature of everyday interaction, enabling researchers to consider ideas in light of their broader historical and argumentative contexts (Billig 1991). In RA research, scholars go beyond the mere identification of different perspectives produced (and reproduced) in discourse. Rather, the goal is to illuminate how people construct certain perspectives to compete with an alternative (Potter and Wetherell 1987). In turn, RA lends itself well to research concerned with how people discuss politically divisive issues (Billig 1987). As my research focused on how participants' framed their perspectives concerning news representations of people seeking asylum, applying both RA and CDA enabled me to shed light on the interesting linguistic and ideological features of these discussions.

I analysed each interview transcript using an inductive approach, which enabled discourses to emerge organically rather than being influenced by predetermined parameters. The first step in this process was to identify instances in each transcript where participants engaged with arguments noted in prior litera- 
ture. I then highlighted instances where interviewees offered ideas that are either not reported (or rarely reported) in existing scholarship. I also noted discourses communicated by more than one participant, enabling the identification of shared collective representations of the emerging themes. Next, I grouped participants' direct quotes into two broad thematic categories: (1) perspectives concerning asylum seekers in Australia; and (2) discussions of news media representations of the topic. I then coded each participant quote according to the broader arguments and discourses they relate to, making note of instances where participants resisted or rejected ideas about asylum seekers presented in media discourse.

\subsection{Theoretical framework: The fake news 'genre' versus fake news 'label'}

This research was guided by the notion that our collective engagement with reliable and factually sound information serves a crucial democratic function. The weaponisation of the concept of fake news is therefore dangerous as it can reduce the capacity of publics to distinguish legitimate news from fake news (Allcott and Gentzkow 2017). This is compounded by evidence that many people equate fake news with information they merely disagree with (e.g. Nielsen and Graves 2017) as well as political actors routinely using the term to delegitimise ideas that challenge their political agenda (Farhall, et al. 2019; Hanitzsch, Van Dalen and Steindl 2018). As Egelhofer and Lecheler (2019) noted, this instrumentalisation by political actors has, to date, received limited empirical attention. In response, Egelhofer and Lecheler (2019) conducted an extensive literature review, which pointed to a fundamental difference between what actually constitutes fake news and how the term is used in political and public discourse. In turn, they proposed a model of analysis whereby fake news is understood as both a genre and a label. The fake news genre describes the deliberate propagation of disinformation in the public sphere, while the fake news label refers to the instrumentalisation of 'fake news' to discredit dissenting ideas (Egelhofer and Lecheler 2019).

While we are seeing growing scholarly focus on the fake news genre, limited research has explored the delegitimising efforts of the fake news label. Indeed, the fake news genre is a highly visible symptom of an increase in publicly communicated disinformation, and requires urgent attention in both a scholarly and policy context due to its insidious contribution to growing inequalities that perpetuate real harm. It is essential, however, to understand how publics deploy the fake news label, and what this tells us about how audiences are making sense of media and political discourse surrounding divisive topics that are vulnerable to disinformation campaigns. Such investigations are crucial because media trust can have a profound impact on citizens' media engagement (Tsfati 2014) and in turn, the fake news label can cause audiences to withdraw from engaging with legitimate 
news content, increasing political polarisation while decreasing access to important information that affects their lives (Carlson 2017).

My research is informed by Egelhofer and Lecheler's (2019) model and as such, I discuss my findings with consideration of how they relate to conceptions of fake news as both a genre and a label. As my findings will illustrate, examining audience perceptions of fake news with consideration of both dimensions offers a focal point for otherwise complex (and oftentimes, contradictory) discourses to coalesce around. Participants drew on numerous discursive constructions of fake news noted in in prior scholarship, adding further veracity to Egelhofer and Lecheler's (2019) model. I unpack these constructions in the following discussion.

\section{Findings and discussion}

\subsection{News engagement and trust}

All participants reported regular engagement with multiple forms of media, and most $(n=22)$ cited Australian news as their main source of information on asylum seekers. They predominantly referred to commercial or 'mainstream' news content, including broadcast bulletins, newspapers, and online news. The majority $(n=18)$ cited social media as their most common means of accessing political information, supporting recent findings that audiences are increasingly engaging with political news via social media (Fisher, et al. 2019; McCollough, et al. 2017; Park, et al. 2020).

When talking about their degree of trust in news representations of asylum seekers, multiple participants raised the issue of false and/or unreliable information. It is important to re-iterate that these interviews took place before the 2016 US election and therefore, before 'fake news' became a popular term. As such, my participants did not explicitly use the label 'fake news'. Nonetheless, I observed strong parallels between participants' discussions of their media trust and constructions of fake news documented in the literature. Of note is the fact that my participants routinely linked their mistrust in news to the intentional presentation of false information (i.e. disinformation), as well as the non-deliberate distortion of facts (misinformation). Additionally, and most interestingly, my findings support the claim that people adopt a discourse of 'fake news' to delegitimise ideas they disagree with (see, for example, Farhall, et al. 2019, and McNair 2018). Thus, my findings provide further empirical support for Egelhofer and Lecheler (2019)'s model of understanding discourses of fake news along two dimensions: the fake news genre and the fake news label. I begin by describing how my interviewees discussed fake news as a genre. 


\section{2 'Force-fed garbage': Discussions of fake news as a genre}

Aligning with most scholarly definitions of 'fake news', several of my participants brought up intentionally misleading content when discussing the factors affecting their trust in Australian news. For instance, many participants used terms such as "biased", "garbage", "crap" and "not authentic" when discussing examples of news media coverage they have encountered about asylum seekers. For example, upon noting that there are certain news outlets she mistrusts due to their representations of asylum seekers, Gillian said:

(1) I hate channel Seven, I hate channel Nine. If I sit and watch, um, one of those, they're just so biased and, like, yeah, it's not authentic.

Female, aged 40-49, Australian, 'accepting' asylum views

Adam shared a similar perspective:

(2) The stuff you get on channel Seven and channel Nine is horrendous. I feel like I'm being force-fed garbage. I just, I really don't know how anyone can believe the stories they are putting out there. There is so much crap.

Male, aged 18-29, Australian, 'accepting' asylum views

These comments specifically reference Seven ${ }^{1}$ and Nine $^{2}$ (two of Australia's most popular news and entertainment networks), with both participants voicing a strong mistrust in the content presented by these networks. Adam's use of the metaphor "force-fed garbage" enables him to emphasise his assertion that their coverage is "horrendous". This is also a useful rhetorical device for signalling his belief that these networks intentionally broadcast disinformation - this is implied by the term "force-fed", which suggests that Seven and Nine actively engage in presenting erroneous content.

As noted, some scholars conceptualise fake news within a broader context of misinformation and disinformation. Here, in addition to deliberate disinformation, fake news is understood to constitute the unintentional presentation of false or exaggerated information (Wardle 2017; Wardle and Derakshan 2017). This conceptualisation has been observed in research involving audience discussions of fake news (e.g. Zaryan 2017). Similarly, some of my participants raised the issue of distorted or unintentionally misleading content when offering their perspectives on the trustworthiness of Australian news. For example, after Jodie stated

1. The Seven Network is a major Australian commercial free-to-air television network owned by Seven West Media.

2. The Nine Network is a major Australian commercial free-to-air television network owned by Nine Entertainment Co. 
that she does not trust most depictions of asylum seekers in the Australian media, she brought up the 2001 'children overboard' incident:

(3) An issue that always bothers me is how the 'party line' becomes the story. Look at how the media portrayed the 'children overboard' affair... this was the point where they completely abandoned all pretence of so-called objective reporting and, well, completely and utterly distorted the public view towards asylum seekers.

Female, aged 40-49, Serbian-Australian 'accepting' asylum views

The 'children overboard' affair occurred when multiple media outlets reported the Australian Government's claims that, while en route to Australia by boat, a group of asylum seekers deliberately threw their children into the ocean to manipulate authorities into granting them refugee status. These claims were later debunked (for a more comprehensive analysis of this event, see Slattery 2003 and Mares 2002). It is important to point out that this incident does not constitute deliberate 'fake news' as media coverage largely parroted the government's take on the incident, which ultimately turned out to be false (however the falsity of the claims was not known at the time the story was initially reported). These statements are nonetheless relevant as many participants framed the incident as an example of mediated misinformation arising from political elites' deliberate distortion of facts to serve a particular agenda. For instance, Jodie's statement "the party line becomes the story" implies that news discourse often reflects the perspectives of politicians, which she suggests can result in a "distorted public view". This is further evidenced by her assertion that, in this particular instance, the Australia media "abandoned all pretence of so-called objective reporting".

Similar sentiments were shared by Jane, who offered the following response when asked to provide an example of news coverage concerning asylum seekers that has impacted her trust in news:

(4) 'Children overboard', as soon as they said that I knew it was all lies, I just knew it. There is no way, women that go through all that and have gotten through all that time on the boat and everything, go and throw in their babies over to drown in that situation. There were no facts. I think that's the part that really annoyed me more than anything else... It was just so obvious that they just took those statements from so-called 'official sources' and ran with it, probably, I think, because it was the more interesting version of the story, despite it being totally fabricated.

Female, aged 50-59, Australian, 'accepting' asylum views

While Jodie's comments attribute the 'children overboard' coverage to the distortion of public perceptions of asylum seekers, suggesting a negative impact on audiences, Jane emphasises that "there were no facts" and states that the story was 
"totally fabricated", which she attributes to news outlets wanting to present the "most interesting version of the story".

In both comments, the falsity of the 'children overboard' story is emphasised, however, neither Jane nor Jodie explicitly position the event as a purely deliberate act on the part of news organisations. Instead, they attribute the story's lack of credibility to the media's reliance on government sources, aligning with prior studies indicating that audiences often mistrust news messages if they sense that they have been influenced by political actors to advance their own interests (McCollough, Crowell and Napoli 2017; Newman and Fletcher 2017). Interestingly, while this appears to represent a common construction of fake news among audiences, there is also evidence that some use the 'fake news' label to legitimise certain ideological positions while discrediting others. In the following discussion, I show how my sample engaged in a similar weaponisation of the 'fake news' label.

\section{3 'Leftist propaganda': Deploying the fake news label}

The way political figures use the 'fake news' moniker to de-legitimise dissenting ideas is beginning to receive more scholarly attention. As Farhall, et al (2019) point out, this discursive weaponisation of fake news undermines democracy by distorting how the public interprets and understands information about important societal issues. My findings offer some support for this, indicating that even before the term 'fake news' rose to prominence, some audiences adopted similar rhetorical strategies by dismissing certain media messages to emphasise their own contrasting ideological positions. These discussions almost exclusively occurred while participants reflected on their trust in Australian news depictions of asylum seekers, however, unlike the discussions offered by participants who linked their mistrust of news to misinformation and disinformation (and thus, discussed fake news as a genre), all participants who deployed the fake news label, articulated 'non-accepting' asylum views.

For instance, after being asked to comment on whether he trusts Australian coverage about people seeking asylum, Reece remarked:

(5) Some of it, yes. But I always tend to think that the more left-wing stuff, it's always gonna [sic] be based on emotion rather than fact. Um, so yeah, to me, in my view, those are more about storytelling than reality.

Male, aged 18-29, Australian, 'non-accepting' asylum views

In response to the same question, Bryan commented: 
(6) I think when it gets too PC and there is this leftist agenda and it takes that, kind of, bleeding hearts angle, that's when I take it with a pinch of salt. Male, aged 40-49, British-Australian, 'non-accepting' asylum views

When asked what he means by 'PC' and 'bleeding hearts angle', Bryan elaborated:

(7) Like, there's this agenda pushing. You know, trying to push sympathy on you, play the sympathy card. To me, all that is just leftist propaganda to push what the Greens want us to think, which is really, really just about tugging at your heartstrings and not telling the truth.

Bryan and Reece's comments both indicate a mistrust in content that presents a view of asylum seekers contrary to their own. Here, they position more sympathetic coverage about asylum seekers as lacking in credibility, which is apparent through their use of language such as "based on emotion rather than fact", "agenda pushing", "propaganda", and "not telling the truth". Bryan's use of terms such as "PC" (i.e. politically correct) and "bleeding hearts angle" are particularly interesting as similar language use has been observed within conservative constructions of asylum seekers (Every 2013; Fozdar and Pedersen 2013). As a rhetorical device, these terms emphasise the divergence between Bryan's stance and that of others who propagate ideas he vehemently rejects.

Another point of interest here is the way both participants link their mistrust in news content to left-leaning political ideologies. While Reece refers to "leftwing" ideas, Bryan uses the term "leftist" and specifically references "the Greens" - a political party known to endorse pro-asylum ideals and policies. This is not surprising given that both participants voiced a 'non-accepting' asylum stance, which is typically associated with right-wing political views. Further, both Reece and Bryan indicated that they voted for the Australian Liberal Party in the 2013 election. Both have therefore exercised democratic decision-making in favour of a political party with stringent and exclusionary asylum policies.

Prior discursive examinations of debates about asylum seekers have revealed that people often make similar references to the political leanings of others while challenging or rejecting ideas they disagree with (e.g. Fozdar and Pedersen 2013). Here, the speaker signals their ideological departure from a certain political 'side' by explicitly contrasting their position with a way of thinking they deem less credible. We see this in Bryan and Reece's comments - both indicate that when news representations of asylum seekers represent left-leaning views, they discount these as "leftist propaganda" (in Bryan's case), or for Reece, "more about storytelling than reality".

Another participant, Beth, similarly connected her asylum stance to her dismissal of the truthfulness of media coverage that presents a sympathetic view of asylum seekers. 
(8) If I'm honest with you, I just don't want them [asylum seekers] here. And I'm not going to change my mind because of false information about their rights and what they've been through where they come from.

Female, aged 30-39, Indigenous-Australian, 'non-accepting' asylum views

Considering Beth prefixed her claim that news coverage concerning asylum seekers' rights and struggles is "false information" by saying "I just don't want them here", it is apparent that she is sceptical of news content that presents a more accepting stance on asylum seekers. She connects this to her own degree of trust by claiming that she is being "taken for a ride" when she is exposed to such ideas in the media.

Similar to Bryan and Reece, Beth engages in the same rhetorical strategy scholars have been observing in conservative political communication, where a discourse of 'fake news' is used to denounce or discredit dissenting perspectives (e.g. Dentith 2017; Farhall, et al. 2019; McNair 2018). All three do this by specifically positioning their perspectives on asylum seekers as being at odds with news material they deem untrue. Here, they use language such as "leftist propaganda", "bleeding hearts angle", and "false information" to indicate their reservations about such coverage. This is also achieved through the use of idioms such as "I take it with a pinch of salt", "taken for a ride", and "tugging at your heartstrings" all of which colourfully emphasise these interviewees' mistrust of more welcoming and liberal asylum discourses. Taken together, these findings lend legitimacy to Egelhofer and Lecheler's (2019) concept of fake news as a label as well as the idea of a 'discourse of fake news', as proposed by Farhall, et al (2019).

\section{Conclusion}

This article examined how a sample of Australian political news consumers discursively constructed misinformation and disinformation before the term 'fake news' entered the lexicon. I focused on these constructions in the context of participants' trust in news depictions of asylum seekers, paying careful attention to how their perspectives compare with conceptualisations of fake news documented in prior literature, notably Egelhofer and Lecheler's (2019) concept of fake news as a label versus fake news as a genre. In line with prior scholarship (e.g. Alcorn and Buchanan 2017; Fisher, et al. 2019; Park, et al. 2020), several participants expressed a mistrust of political news coverage, with many discussing instances where they believe media agencies have either deliberately or inadvertently misled the public about people seeking asylum. This was most commonly observed for participants with 'accepting' and 'ambivalent' views toward asylum 
seekers. Participants who expressed opposition to Australia's acceptance of asylum seekers, however, demonstrated a notably different mechanism for discussing their trust and mistrust of news. Here, I observed participants' weaponisation of the 'fake news' label in a similar manner to observations in prior scholarship where the term is used as a rhetorical device to discredit media messages that contradict certain ideological positions (Dentith 2017; Farhall, et al. 2019; McNair 2018; Wardle and Derakhshan 2017). More specifically, it was common for these participants to deploy the 'fake news' label while denouncing ideas that counter their opinions about seeking asylum. This suggests that some of the discursive strategies employed by conservative elites are reflected in discussions among the wider Australian public when discussing mediated depictions of asylum seekers. As Egelhofer and Lecheler $(2019,108)$ assert:

The news media is afflicted by a culture of permanent criticism in a digitalized political discourse and a new class of populist politicians, who attack journalists at a time when they are economically and socially vulnerable. Anti-elitist tendencies in many western democracies have made way for public doubts as to the performance of the fundamental institutions that uphold these democracies, such as science, politics and journalism. The use of the fake news label is a further symptom of this affliction.

My research adds weight to Egelhofer and Lecheler's (2019) framework by illuminating how audiences reproduce the weaponisation of fake news within their own critical discussions of media discourse, and how for many, the 'fake news' label becomes an effective rhetorical device for asserting their own positions on the topic of people seeking asylum.

As this research was conducted prior to 'fake news' becoming a common term in public and political discourse, it was not possible to measure how my sample conceptualised the term itself. Future studies could therefore benefit from exploring how audiences explicitly define fake news, particularly within discussions about media coverage on divisive issues such as asylum seekers. This could further clarify whether audiences are prone to adopt discursive strategies used by political elites who decry 'fake news' to stifle dissent. We also need more empirical investigations into the conditions by which the fake news label is deployed (i.e. whether it is predominantly applied to single articles and/or outlets, or if it is typically generalised to 'the media' - as observed in the current study). Nonetheless, by shedding light on how, even before we had a popular name for the phenomenon, people were making sense of fake news as both a genre and a label (Egelhofer and Lecheler 2019), my research demonstrates how scholars can examine audience responses to both historical and contemporary news events. This can open up opportunities for comparing the different ways in which publics have 
discussed their trust in news both before and after the term 'fake news' became ubiquitous within public and political discourse.

\section{Funding}

This research was supported by an Australian Government Research Training Program (RTP) Scholarship, undertaken at the University of Western Australia.

\section{Acknowledgements}

In addition to the anonymous reviewers, who offered invaluable feedback on this article, I want to thank Associate Professor Farida Fozdar from the University of Western Australia and Professor Rob Cover from RMIT University for their guidance and support with this research project. I would also like to extend my sincerest thanks to Professor Scott Wright (Monash University) and Dr Samuel Bennett (Assistant Editor of the Journal of Language and Politics) for facilitating this important and poignant special issue.

\section{Declaration of interest statement}

No potential competing interest was reported by the authors.

\section{References}

Alcorn, Niki, and Lucy Buchanan. 2017. Media consumer survey 2017: Australian media and digital preferences, 6 th edition. Sydney: Deloitte.

Allcott, Hunt, and Matthew Gentzkow. 2017. "Social media and fake news in the 2016 election". Journal of Economic Perspectives 31(2): 211-236. https://doi.org/10.1257/jep.31.2.211

Bakir, Vian, and Andrew McStay. 2017. "Fake news and the economy of emotions: problems, causes, solutions". Digital Journalism 6(2): 154-175.

https://doi.org/10.1080/21670811.2017.1345645

Baym, Geoffrey. 2005. "The Daily Show: Discursive integration and the reinvention of political journalism". Political Communication 22(3): 259-276.

https://doi.org/10.1080/10584600591006492

Billig, Michael. 1987. Arguing and thinking: A rhetorical approach to social psychology. Cambridge: Cambridge University Press.

Billig, Michael. 1991. Ideology and opinions: Studies in rhetorical psychology. London: Sage. Brummette, John, Marcia DiStaso, Michail Vafeiadis and Marcus Messner. 2018. "Read all about it: The politicization of "fake news" on Twitter." Journalism and Mass Communication Quarterly 95(2), 497-517. https://doi.org/10.1177/1077699018769906 
Carlson, Matt. 2017. Journalistic authority: Legitimating news in the digital era. New York City: Columbia University Press. https://doi.org/10.7312/carl17444

Clyne, Michael. 2005. "The use of exclusionary language to manipulate opinion: John Howard, asylum seekers and the re-emergence of political correctness in Australia". Journal of Language and Politics 4(2): 173-196. https://doi.org/10.1075/jlp.4.2.03cly

Cooke, Nicole. A. 2017. "Posttruth, truthiness, and alternative facts: Information behavior and critical information consumption for a new age". The Library Quarterly 87(3): 211-221. https://doi.org/10.1086/692298

Dentith, Matthew R.X. 2017. “The problem of fake news”. Public Reason 8(1-2): 65-79.

Egelhofer, Jana Laura, and Sophie Lecheler. 2019. "Fake news as a two-dimensional phenomenon: A framework and research agenda". Annals of the International Communication Association 43(2): 97-116. https://doi.org/10.1080/23808985.2019.1602782

Ellis, Katherine, Janet Fulton and Paul Scott. 2016. "Detention attention: framing a Manus Island riot”. Pacific Journalism Review: Te Koakoa 22(1): 74-92. https://doi.org/10.24135/pjr.v22i1.13

Every, Danielle. 2013. "'Shame on you': The language, practice and consequences of shame and shaming in asylum seeker advocacy". Discourse and Society 24(6): 667-686. https://doi.org/10.1177/0957926513486223

Fairclough, Norman. 1992. Discourse and social change. Cambridge: Polity Press.

Farhall, Kate, Andrea Carson, Scott Wright, Andrew Gibbons, and William Lukamto. 2019. "Political elites' use of fake news discourse across communications platforms". International Journal of Communication 13(23): 4353-4375.

Fisher, Caroline, Sora Park, Jee Young Lee, Glen Fuller and Yoonmo Sang. 2019. Digital news report: Australia 2019. Canberra: University of Canberra.

Flood, Alison. 2017. "Fake news is 'very real' word of the year for 2017”. The Guardian (2 November). Retrieved 6 September 2020 , from: https://www.theguardian.com/books /2017/nov/o2/fake-news-is-very-real-word-of-the-year-for-2017

Fozdar, Farida, and Anne Pedersen. 2013. "Diablogging about asylum seekers: Building a counter-hegemonic discourse". Discourse and Communication $7(4): 371-388$. https://doi.org/10.1177/1750481313494497

Gelfert, Axel. 2018. "Fake news: A definition”. Informal Logic 38(1): 84-117. https://doi.org/10.22329/il.v38i1.5068

Gil de Zúñiga, Homero, and Trevor Diehl. 2018. "News finds me perception and democracy: Effects on political knowledge, political interest, and voting". New Media and Society 21: 1253-1271. https://doi.org/10.1177/1461444818817548

Hanitzsch, Thomas, Arjen Van Dalen, and Nina Steindl. 2018. "Caught in the nexus: A comparative and longitudinal analysis of public trust in the press." The International Journal of Press/Politics 23(1): 3-23. https://doi.org/10.1177/1940161217740695

Haw, Ashleigh L. 2018. 'I take it with a pinch of salt': Discursive responses to news representations of asylum seekers among Western Australian media audiences (Doctoral Dissertation). Crawley, WA: The University of Western Australia.

Higgins, Claire. 2017. Asylum by boat: Origins of Australia's refugee policy. Sydney: UNSW Press.

Johnson, Thomas J., and Kaye, Barbara K. 200o. "Using is believing: The influence of reliance on the credibility of online political information among politically interested internet users". Journalism and Mass Communication Quarterly 77: 865-879. https://doi.org/10.1177/107769900007700409 
Juhász, Attila, and Patrik. 2017. The political effects of migration-related fake news, disinformation and conspiracy theories in Europe. Budapest: Friedrich Ebert Stiftung, Political Capital Policy Research and Consulting Institute.

Lokot, Tetyana, and Nicholas Diakopoulos. 2016. "News bots: Automating news and information dissemination on Twitter". Digital Journalism 4(6): 682-699. https://doi.org/10.1080/21670811.2015.1081822

Lueck, Kerstin, Clemence Due and Martha Augoustinos. 2015. Neoliberalism and nationalism: Representations of asylum seekers in the Australian mainstream news media. Discourse and Society 26(5): 608-629. https://doi.org/10.1177/0957926515581159

Mares, Peter. 2002. Borderline: Australia's response to refugees and asylum seekers in the wake of the Tampa. Sydney: UNSW Press.

McBride, Kelly, and Tom Rosenstiel (eds). 2013. The new ethics of journalism: Principles for the 21st century. Washington, D.C: CQ Press.

McCollough, Kathleen, Jessica K. Crowell, and Philip M. Napoli. 2017. "Portrait of the online local news audience". Digital Journalism 5(1): 100-118. https://doi.org/10.1080/21670811.2016.1152160

McNair, Brian. 2018. Fake news: Falsehood, fabrication and fantasy in journalism. Oxon, UK: Routledge.

Muller, Denis. 2016. Islamisation' and other anxieties: Voter attitudes to asylum seekers. Melbourne: The University of Melbourne.

Nielsen, Rasmus Kleis, and Lucas Graves. 2017. 'News you don't believe': Audience perspectives on fake news. Oxford, UK: Reuters Institute for the Study of Journalism.

Nelson, Jacob L., and Harsh Taneja. 2018. "The small, disloyal fake news audience: The role of audience availability in fake news consumption". New Media and Society 20(10): 3720-3737. https://doi.org/10.1177/1461444818758715

Newman, Nic, and Richard Fletcher. 2017. Bias, bullshit and lies: Audience perspectives on low trust in the media. Oxford, UK: Reuters Institute.

Noy, Chaim. 2008. "Sampling knowledge: The hermeneutics of snowball sampling in qualitative research”. International Journal of Social Research Methodology 11(4): 327-344. https://doi.org/10.1080/13645570701401305

Park, Sora, Caroline Fisher, Jee Young Lee, Kieran McGuinness, Yoonmo Sang, Mathieu O’Neil, Michael Jensen, Kerry McCallum and Glen Fuller. 2020. Digital news report: Australia 2020. Canberra: News and Media Research Centre, University of Canberra.

Philo, Greg, Emma Briant, and Pauline Donald. 2013. Bad News for Refugees. Pluto Press.

Pickering, Sharon. 2001. "Common sense and original deviancy: News discourses and asylum seekers in Australia”. Journal of Refugee Studies 14(2): 169-186. https://doi.org/10.1093/jrs/14.2.169

Potter, Jonathan. W., and Margaret Wetherell. 1987. Discourse and social psychology. London: Sage.

Slattery, Kate. 2003. "Drowning not waving: The 'children overboard' event and Australia's fear of the other". Media International Australia 109(1): 93-108. https://doi.org/10.1177/1329878X0310900110

Slavíčková, Tess, and Peter Zvagulis. 2014. "Monitoring anti-minority rhetoric in Czech print media: A critical discourse analysis." Journal of Language and Politics 13(1): 152-170. https://doi.org/10.1075/jlp.13.1.07sla 
Sutherland, Andrew. D., and Tiffany. A. Dykstra-DeVette. 2018. "Constructing identification and division through fake news reports of refugees". Language Discourse and Society 6(1): 15-31.

Tandoc, Edson. C., Zheng Wei Lim and Richard Ling. 2018. "Defining 'fake news': A typology of scholarly definitions". Digital Journalism 6(2): 137-153. https://doi.org/10.1080/21670811.2017.1360143

Titscher, Stefan, Michael Meyer, Ruth Wodak and Eva Vetter. 200o. Methods of text and discourse analysis. London: Sage.

Tsfati, Yariv. 2003. "Does audience skepticism of the media matters in agenda setting?" Journal of Broadcasting and Electronic Media 47(2): 157-176. https://doi.org/10.1207/s15506878jobem4702_1

Tsfati, Yariv. 2014. Uses and perceptions of political media. In Reinemann, Carsten (ed). Political communication, 489-506. Berlin: de Gruyter Mouton. https://doi.org/10.1515/9783110238174.489

Tsfati, Yariv, and Cappella, Joseph N. 2003. "Do people watch what they do not trust? Exploring the association between news media skepticism and exposure". Communication Research 30(5): 504-529. https://doi.org/10.1177/0093650203253371

van Dijk, Teun. A. 200o. "New(s) racism: A discourse analytical approach”. Ethnic Minorities and the Media 37: 33-49.

Van Duyn, Emily, and Jessica Collier. 2019. "Priming and fake news: The effects of elite discourse on evaluations of news media”. Mass Communication and Society 22(1): 29-48. https://doi.org/10.1080/15205436.2018.1511807

Wardle, Claire. 2017. “Fake news. It's complicated”. Retrieved 9 September 2020, from: https:// medium.com/1st-draft/fake-news-its-complicateddof $773766 \mathrm{c} 79$

Wardle, Claire, and Hossein Derakhshan. 2017. "Information disorder: Toward an interdisciplinary framework for research and policymaking”. The Council of Europe. Retrieved 9 September 2020, from: https://shorensteincenter.org/wp-content/uploads /2017/10/PREMS-162317-GBR-2018-Reportde\%CC\%81sinformation.pdf?x78124

Willig, Carla. 2008. Introducing qualitative research in psychology: Adventures in theory and method. Milton Keynes: Open University Press.

Wodak, Ruth, and Michał Krzyżanowski. 2017. "Right-wing populism in Europe and USA: Contesting politics and discourse beyond 'Orbanism' and 'Trumpism”'. Journal of Language and Politics 16(4): 1-14. https://doi.org/10.1075/jlp.17042.krz

Young, Sally. 2011. How Australia decides: Election reporting and the media. Port Melbourne: Cambridge University Press.

Zaryan, Stella. 2017. Truth and trust: How audiences are making sense of fake news. Lund: Lund University. 


\section{Address for correspondence}

Ashleigh L. Haw

School of Social and Political Sciences

The University of Melbourne

E574, Level 5, John Medley Building

Parkville Victoria 3051

Australia

ahaw@unimelb.edu.au

\section{Biographical notes}

Ashleigh Haw is a Research Fellow in the School of Social and Political Sciences at the University of Melbourne, Australia. Her research focuses on discursive constructions of marginalised groups in media, political and public discourse, with emphasis on the implications for democracy, human rights, and social cohesion.

(iD) https://orcid.org/0000-0001-5080-1699

\section{Publication history}

Date received: 16 September 2020

Date accepted: 12 May 2021

Published online: 16 July 2021 